Marquette University

e-Publications@Marquette

Philosophy Faculty Research and Publications

Philosophy, Department of

6-1-2004

\title{
Environmental Education and Metaethics
}

Owen Goldin

Marquette University, owen.goldin@marquette.edu

Accepted version. World Views: Environment, Culture, Religion, Vol. 8, No. 2-3 (June 2004): 185-197. DOI. (C) 2004 Brill Academic Publishers. Used with permission. 


\title{
Environmental Education and Metaethics ${ }^{1}$
}

\author{
Owen Goldin \\ Department of Philosophy, Marquette University \\ Milwaukee, WI
}

\begin{abstract}
Contrà Dale Jamieson, the study of the metaethical foundations of environmental ethics may well lead students to a more environmentally responsible way of life. For although metaethics is rarely decisive in decision making and action, there are two kinds of circumstances in which it can play a crucial role in our practical decisions. First, decisions that have unusual features do not summon habitual ethical reactions, and hence invite the application of ethical precepts that the study of metaethics and ethical theory isolate and clarify. Second, there are times in which the good of others (including organisms and systems in the natural world) may well be given greater weight in one's ethical deliberations if theory has made clear that the good to be promoted is ontologically independent of one's own good.
\end{abstract}

Keywords: Environmental ethics, environmental education, environmental value, metaethics, Dale Jamieson

\section{Introduction}

Classes in environmental ethics are increasingly common at the college level. Often, these classes focus on the question of the metaphysical status of the value or goodness to be ascribed to entities and systems in the natural world. ${ }^{2}$ Is value inherent in Nature? Does it 
originate and exist in the mind of the one who recognizes the value? Are there other possibilities?

Here I would like to discuss the role that such questions play in environmental education. The study of environmental philosophy is meant to stimulate critical reflection on the relationship between human beings and the natural environment. We may well think that this reflection will lead to better attitudes and actions in regard to the environment. Is this a reasonable belief? More specifically, does exploring philosophical questions concerning the source and ontological basis of value contribute to what many take to be the central task of classes in environmental ethics: cultivating the attitudes that lead to appropriate action in regard to the natural world? ${ }^{3}$

An ethical theory clarifies the good to be promoted and identifies what a moral agent is obligated to do in the pursuit of this good. A metaethics grounds and justifies this ethical theory on the basis of an account of rationality, human nature and the larger world of which it is a part. A metaethics often employs a metaphysics, which discusses the underlying structures and realities that are responsible for the obligations that the ethical theory presents. But despite the fact that many Western ethical theories are grounded in metaphysical theory, the thesis that metaphysics can or should make a difference in the morality of our action is by no means uncontroversial. Dale Jamieson in particular has argued against this. ${ }^{4}$ I think that he is right to deemphasize the importance that metaphysical metaethics plays in people's actual decisions and ways of life. I do however think that there are important exceptions to Jamieson's view, and that one of these is environmental ethics, an area in which Jamieson has specialized.

The question of the metaphysical basis of value has had an important role to play in the emerging field of environmental ethics. Much ink has been spilt trying to show that natural things and systems have value in and of themselves, not to be understood as a means to the actualization of some other good, and not to be taken as always derived from a mental or emotional attitude that people take towards them, in order to show that there is a moral obligation to preserve them, regardless of whether they contribute to human interests. ${ }^{5}$ Given the philosophical temper of our times, such speculation is wont to seem metaphysically extravagant, out of sync with the hard

Worldviews, Vol 8, No. 2-3 (June 2004): pg. 185-197. DOI. This article is (C) Brill Academic Publishers and permission has been granted for this version to appear in e-Publications@Marquette. Brill Academic Publishers does not grant permission for this article to be further copied/distributed or hosted elsewhere without the express permission from Brill Academic Publishers. 
sciences and smacking of mysticism. One might think "if environmental ethics rests on such dubious foundations, so much the worse for environmental ethics." This is why Jamieson, with his special interest in the field, takes it upon himself to argue that environmental ethicists can be spending their time more productively than by arguing over metaphysics. I argue here that there are special features to the field of environmental ethics that give special importance to theorizing concerning the conceptual and ontological underpinnings of ethics. One need not explicitly engage in metaethics or metaphysics in order to have a worthy ethical attitude towards the natural world. But in this area, at any rate, such speculation has the potential for making a decisive difference in our praxis.

\section{Metaphysics and Ethics}

Metaphysics and ethics have long been intertwined. Ethical theory often explicitly rests on a metaphysical foundation, and the data of ethics are among the givens that form the raw material of metaphysical analysis. But to what extent is metaphysics involved in ethical deliberation and action? It seems that it has an important role to play only insofar as it has an essential role in ethical theory, and insofar as ethical theory plays an essential role in ethical judgment and decision making. But must one engage in ethical theory in order to act ethically? Perhaps only Plato, the Stoics and Kant set the bar so high. It is well known how Plato makes philosophy necessary for right action. From the earlier dialogues to the Republic, Socrates insists that one must have a special knowledge of the good, in order to achieve what is good. For the Stoics, right action is possible only for the sage, whose mind penetrates the underlying logos of the cosmos. For this reason, Stoics were forced to admit that almost all, if not all, human beings were fools and acted accordingly. Kant, on the other hand, was more optimistic concerning the abilities of unschooled everyday reason. For Kant, ethical action is rational action, and necessarily involves an application of the Categorical Imperative, but this is not an application of theory and does not require of the agent any excursion into metaethics. Other Western ethical philosophical traditions also seem less committed to the role played by ethical theory and its metaphysical foundation as prerequisites for ethical action. To be sure, Aristotle tells us that a theoretical account of the human good gives us

Worldviews, Vol 8, No. 2-3 (June 2004): pg. 185-197. DOI. This article is (C) Brill Academic Publishers and permission has been granted for this version to appear in e-Publications@Marquette. Brill Academic Publishers does not grant permission for this article to be further copied/distributed or hosted elsewhere without the express permission from Brill Academic Publishers. 
a target at which to aim (NE I.2), but this may be a glance at either the political implications of the ethics (since a leader needs to clearly see the telos of the community) or Book 10's encouragement of the contemplative life, neither a fundamental part of the everyday morality of the private citizen. Rather, for most people the moral life comes through the ethical habituation that results from obeying the law and following the example of the phronimos, the person of practical wisdom. This is similarly the case in Natural Law theory, whose underlying metaphysics is more involved and has a more explicit role to play in ethical theory than that of Aristotle's ethics from which it is largely derived. Finally, ethical theories such as that of Hume or classical utilitarianism which ground ethics on human sentiment hold that the study of ethical theory may refine our sentiments and render them consistent with each other, but cannot serve to instill the core sentiments of fellow-feeling that underlie morality. Such theories often explicitly dispense with metaphysical speculation, since the core moral sentiments are taken as empirically given and not to be justified by any more basic account.

For this reason, it appears that Jamieson is battling something of a straw man; to dissuade us from overemphasizing the issue of the metaphysical foundations of value in nature, he writes that ethical realists understand metaethics "as some immaculate conception that sits in judgment of our practices" or "part of a reforming philosophical project . . . philosophy run amok."6 Jamieson tells us that "philosophy, understood as the appreciation of, and reflection on, our practices, leaves the world alone. It may inform and incline our thoughts, but it cannot determine them."7 Platonists, Cynics, and Stoics aside, no major figure in the Western philosophical tradition has thought otherwise (except insofar as the activity of philosophy itself is taken to be constitutive of the good life). Engaging in metaethics or metaphysics has rarely been taken to be required for living in a decent manner. More particularly, it would be astonishing to claim that a class in environmental ethics is a prerequisite for the cultivation of ecologically responsible habits.

However, even if one can act perfectly morally without expertise in metaphysics, I can imagine three kinds of cases in which people's actions can be affected by virtue of engaging in ethical theory and metaethics. These are worth mentioning, even though in the first two kinds of cases it is not philosophical thought as such that is decisive,

Worldviews, Vol 8, No. 2-3 (June 2004): pg. 185-197. DOI. This article is (C) Brill Academic Publishers and permission has been granted for this version to appear in e-Publications@Marquette. Brill Academic Publishers does not grant permission for this article to be further copied/distributed or hosted elsewhere without the express permission from Brill Academic Publishers. 
and hence these do not dislodge Jamieson's point concerning the impracticality of theories concerning the ontology of value.

(1) If we antecedently assume that consistency is a good for which we should strive, ethical theory is useful in making sure that our judgments are consistent. We may give up or alter an ethical judgment when we see that it is inconsistent with other judgments or beliefs to which we are committed. This is the stuff of Socratic elenchus, and at their best we see this sort of thing in our introductory ethics classes. Students who are committed to certain ethical principles can be led to see that they implicitly clash with certain judgments they make. This can lead people to revise these judgments and to make different choices. But typically in such a case the students come to isolate and apply foundational ethical precepts, and to identify certain goods and duties at a general level. Discussion need not extend to the level of metaphysical analysis, explaining what it is about the world that makes these goods desirable and gives these duties their binding character.

For example, one might be led to see that the right to life entails a right to a modicum of health care, and one's political allegiances could conceivably change as a result of such an argument. But how would this depend on a metaphysical account of human nature that explains what it is about human beings that gives them a right to life? Similarly, students who already take cruelty to animals to be a moral evil can be shown that certain practices in factory farming, or even purchasing food that derives from such practices, is inconsistent with their initial assumptions. Those who already value biodiversity can be shown that this ethical commitment is incompatible with the typical American lifestyle. But such reflection does not rest on investigating the theoretical foundations of value. To show consistency or inconsistency in a set of views does not depend on any particular theoretical grounding of ethics - all that is required is an account of principles and basic precepts, and the ability to think logically.

(2) An ethical theory may have certain pragmatic value that is to a certain extent independent of its philosophical value. It was Plato, in the Laws, who first suggested that philosophy is not only for philosophers - the very fact that an already respected authority presents a logos (argument) in support of a rule makes a citizen more inclined to follow and uphold that rule, even though he or she is not capable of fully understanding that argument. ${ }^{8}$ In this way, a priest

Worldviews, Vol 8, No. 2-3 (June 2004): pg. 185-197. DOI. This article is (C) Brill Academic Publishers and permission has been granted for this version to appear in e-Publications@Marquette. Brill Academic Publishers does not grant permission for this article to be further copied/distributed or hosted elsewhere without the express permission from Brill Academic Publishers. 
might argue for a certain moral view on the basis of Natural Law theory. The argument may be only half-understood by his congregants, but the very fact that the argument is there may give the position greater weight than it would have had only on the basis of the priest's personal or ecclesiastical authority. Similarly, the Talmud rests on a metaphysics (not all of which can be supported on strictly philosophical grounds). As an observant Jew, my study of Talmud can motivate me in adhering to Jewish law with greater diligence than I would simply on the basis of rabbinical authority unsupported by argument. This is so in spite of the rudimentary nature of my understanding of Talmudic reasoning. This is because arguing for a conclusion is a powerful rhetorical device for persuading others of that conclusion. The fuller the argument (that is, the greater the extent that it is based only on agreed-upon premises), and the more it is adequately understood, the more convincing the argument is. This is so, even if, as is always (or nearly always) the case, the argument is not fully grasped, from its foundations through its intervening steps.

If I understand Jamieson correctly, it is here that one finds metaethics to have some pragmatic value. Ontological claims are made in order to provide foundations and fill in the gaps found in ethical argumentation. An argument containing as an unsupported premise the claim that others ought to value some entity or state of affairs is less full than one that grounds this premise in some general ontology. In so arguing, we speak in a way that reifies our act of valuing and presents the value found as something independent of that act, and accordingly as something to be considered in everyone's ethical deliberations, regardless of perspective or interests. We do this as a rhetorical ploy, to get others to act as we would like them to, for we are suggesting that the value is "out there," available for them too to recognize, if only they would see. An ethical theory, which pretends to take this value as its object and study it apart from the psychological and social conditions of the acts of valuing that give rise to it, is part of this same rhetorical enterprise. ${ }^{9}$ Thus, Jamieson writes: "In everyday life, we commit acts of metaethics when reflective thought, unreflective argument, or the simple pressure of serious disagreement takes us to the brink of a rhetorical abyss. At such moments we employ metaethical strategies in the service of our practical ends." 10 It cannot be denied that discussion of the metaphysical bases of ethical theory can play this role, sometimes

Worldviews, Vol 8, No. 2-3 (June 2004): pg. 185-197. DOI. This article is (C) Brill Academic Publishers and permission has been granted for this version to appear in e-Publications@Marquette. Brill Academic Publishers does not grant permission for this article to be further copied/distributed or hosted elsewhere without the express permission from Brill Academic Publishers. 
effectively. In cases of this kind, too, it is not the metaphysics behind the theory that gives it its practical import, except insofar as those argument fragments that are comprehended make the whole account more persuasive. In this way, a student might only half-understand the arguments behind the land ethic, but the air of authority and the persuasive manner of a teacher of environmental ethics who lays out the theoretical foundations of the land ethic may predispose the student to accept it, and the parts of the argument that the student does understand may be decisive in her coming to say to herself "Makes sense to me." She may come to call herself an adherent of the land ethic, something that might never have happened had she not sat through lectures and discussions covering material she inadequately grasps. This may well be decisive in later leading the student to avoid applying pesticides on her lawn, and so forth.

(3) I should not omit to mention the kind of thing that we see in Plato's dialogues, and that hopefully goes on in our classes, including those in environmental ethics. Through leading students to engage in the activity of philosophical reflection (including metaethical reflection) students can learn for themselves that this activity is intrinsically valuable, and it may come to form part of their conception of the good life. This may indeed lead to some practical decisions: from the decision to join a philosophy reading group to devoting one's life to metaphysics. But, on the face of it, this does not seem different from the practical implications of being introduced to fine French cuisine. To show otherwise requires the sort of theoretical argumentation whose practical value is at issue.

(4) There is one more kind of case in which a metaphysical metaethics can conceivably lead to the making of new and more enlightened decisions. I suspect that it is this sort of case that both the champions and detractors of the practicality of metaphysical metaethics have in mind in their disputes. One may accept an ethical theory, with all of its metaphysical framework, on the merits of supporting arguments, which are indeed adequately understood. Then one may come to make certain ethical judgments on account of the fact that this theory demands it. The theory itself may be responsible for ethical choices. Thus an argument based on an ethical theory may lead to an unanticipated conclusion - it is at least imaginable that a slaveowner may have seen the error of his ways as a result of reading Kant closely and carefully. Further, when ethical obligations come in 
conflict, a theory can help prioritize ethical demands. An example might be an intricate argument applying the Thomistic doctrine of double effect to an ethical dilemma. It is my contention that this happens rarely, with important exceptions. One exception is the area of environmental ethics.

I do not here set for myself the task of proving the negative claim, concerning the rarity of case number 4 . Nietzscheans and other antitheorists are better able to do this than I am. Besides, as I have mentioned, few such cases are attested within the Western philosophical tradition. Here I aim to argue that the area of environmental ethics has distinctive characteristics, so that the sort of metaphysical reflection that is invited by ethical thought experiments may be decisive in the formulation of new ethical judgments.

\section{Metaphysical Reflection and Environmental Ethics}

I begin with a thought experiment that has become something of a chestnut in the area of environmental ethics. I lay it out not in order to adequately evaluate whether it is successful in isolating a "metaphysical intuition" concerning the value of the natural world (I think it is) but in order to explore its purported role as foundational to an environmental ethics that makes a real difference in practice.

The thought experiment I would like to consider was formulated by Richard Routley at the dawn of environmental philosophy as such. ${ }^{11}$ Imagine a last man, who takes it in his head to destroy the living things and ecosystems that would otherwise survive him. Our immediate unreflective response would be to say that there would be something very wrong about this. Thus, Routley argues, our thought experiment shows that nonhuman beings have inherent value. There is a goodness to them that is not dependent on the thought processes of an evaluator; for, in the situation under consideration, the evaluator is absent from the scene. Routley argued that, insofar as traditional Western ethics is not able to account for this value, it is deficient, and ethics needs a new foundation. Thus environmental ethics as a distinctive discipline is born.

There are various ways of countering Routley's claim, and various ways in which it can be defended, some of which Routley himself offered to critics both potential and actual. I have much to say on this, which I hope to soon offer the community of environmental

Worldviews, Vol 8, No. 2-3 (June 2004): pg. 185-197. DOI. This article is (C) Brill Academic Publishers and permission has been granted for this version to appear in e-Publications@Marquette. Brill Academic Publishers does not grant permission for this article to be further copied/distributed or hosted elsewhere without the express permission from Brill Academic Publishers. 
ethicists. But I here avoid such ontological speculation, since my present task is to wonder what effect such exploration has on actual conduct. More specifically, what effect could a college philosophy class in which such metaphysical argumentation plays a dominant role have on the actual behavior of students taking it? Could it conceivably lead to a more environmentally responsible life, after the examinations and paper assignments are long forgotten?

Suppose that someone finds Routley's argument philosophically convincing. What has happened? A thought experiment shows that certain things are good independent of human valuation and hence shows the inadequacy of a metaethics that denies this. Accordingly, an alternative ethical theory is required, which gives some ontological status to such goodness. This theory both posits value outside of the human realm (a move with which Jamieson and Callicott have no objection) and takes the source of that value to lie outside of the human realm (which these two authors deny). Hence, one adopts the new ethical theory and its metaphysical commitments because it has greater explanatory power than its rivals.

The metaphysical speculation at issue is not a prerequisite for finding noninstrumental value in nature. Rather, the thought experiment is prior to such speculation, and shows that we do find such value in nature, regardless of any metaphysical thought or theorizing concerning the source of this value. In everyday life, we may well have made decisions to preserve such value, whether through practicing organic gardening, keeping on the trails to prevent erosion, or giving money or time to an environmental cause. But such decisions could well have been made in the interests of human beings: who is clear about his motives? The thought experiment is meant to provide some clarity here, by postulating a case in which the decision cannot be made for the sake of people who take an actual interest in the bearers of goodness, since by hypothesis there are no people to take such an interest. Yes, this is an extreme case, of a sort that people will not encounter in their day to day decision making, the sort of science fiction example to which teachers of introductory ethics too often resort. But these cases have their use: they provide what the real world does not, ways of imaginatively abstracting decisions from surrounding circumstances. If one is trying to prove that a certain factor $X$ is (or can be) decisive in ethical decision-making, one strains to set up an example where another factor $Y$, which is often taken to

Worldviews, Vol 8, No. 2-3 (June 2004): pg. 185-197. DOI. This article is (C) Brill Academic Publishers and permission has been granted for this version to appear in e-Publications@Marquette. Brill Academic Publishers does not grant permission for this article to be further copied/distributed or hosted elsewhere without the express permission from Brill Academic Publishers. 
be decisive, cannot be not operative. (For example, in our introductory ethics classes we set up implausible examples where using another as a mere means, through the infliction of pain, would without question be for the greatest good for the greatest number, an evaluation always questionable in the real world, in order to prove the Kantian principle that one ought not use another rational being merely as a means.) Here, a principle to be demonstrated is that natural beings have value or worth that is not dependent or derivative on the activity of valuing, and this is done by setting up the example in such a way that the possibility of an evaluator is excluded. To be sure, even if one accepts the results of the thought experiment, the theory that one is committed to is somewhat minimal. All that has been shown is that there is value in the natural world that is not dependent on the activity of valuing. It is left to further theorizing to say what the bearer of this value is (individual organism? ecosystems?), and what it is about the world that is responsible for it. The nature of value is unclear, and nothing is revealed concerning its relation to naturalistic properties. Similarly nothing is said about our epistemological access to them. Still, the existence of such value is an ontological claim, one that is quite explicitly a piece of metaphysics. Admittedly, the thought experiment raises a swarm of further metaphysical and epistemological problems, but metaphysical accounts need to start somewhere, and the existence of value that is neither anthropocentric nor anthropogenic, indicated by the kind of thought experiment that Routley explores, is at least a possible metaphysical principle.

I claim that in this case, when a new ethical theory is in place, with the metaethical commitment to value in nature ontologically independent of human valuation, judgments will be made that would otherwise not have been made. This has a real effect in regard to our personal decisions and public policy decisions. Consider for example public policy debates concerning wilderness preservation. It is true that one does not need a metaphysical account of value as inherent in natural systems and the living things within them, in order to see that wilderness preservation can be a good thing. One may find pleasure in the knowledge that a bit of wilderness exists, apart from any theorizing. Wilderness can be valued on instrumental grounds: it is good for the psychological wellbeing of a country's citizens, it provides an irreplaceable kind of pleasure that would rank high on the kind of qualitative scale we see in Mill, it preserves species that may have

Worldviews, Vol 8, No. 2-3 (June 2004): pg. 185-197. DOI. This article is (C) Brill Academic Publishers and permission has been granted for this version to appear in e-Publications@Marquette. Brill Academic Publishers does not grant permission for this article to be further copied/distributed or hosted elsewhere without the express permission from Brill Academic Publishers. 
unanticipated uses, it is good for clean air, clean water, and so forth. But on such an account the question of how much wilderness to preserve quickly becomes one of balancing these goods with other goods whose value arises from human thought and desire. To be sure, such prudential balancing would be required even if we were to recognize value that things in the natural world have in themselves, regardless of whether or not their worth is recognized or recognizable by evaluators. But in those cases in which we know that there are few people with enough awareness to enable us to say that they truly value what is at issue (for example, vast stretches of the Arctic National Wildlife Reserve, which for most people exist only as blank areas on a map) citizens may well make different decisions, by virtue of their new explicitly theoretical commitments. The matter at hand may call to mind the principle that wilderness has value, and that it follows that public policy must take account of this. The situation stands in contrast to a public policy matter that concerns human beings alone. There we are on more familiar ethical ground. Our desires to clothe the poor and feed the hungry are familiar responses to certain kinds of situations, as are our desires to inculcate selfreliance and practice fiscal responsibility. How to balance competing ethical demands is a matter of prudential judgment. But an explicit ethical theory, with all of its metaphysical underpinning, will rarely be the occasion for the judgments made here. This is because the situations are not so unusual or unfamiliar as to immediately call to mind the ethical theorizing to which one has been exposed, in however fragmentary a form.

A similar sort of example is that which concerns citizens and policymakers in the areas of food and reproductive technologies. Ought crops to be genetically modified? To be sure, such cases lend themselves to standard consequentialist analyses. Is the food safe? What will happen as the variety of seed stock is diminished? But some who consider the prospect of a tomato with the genes of a pig, say, may initially experience revulsion, and this may occasion the realization that living things belong to kinds with an integrity that has noninstrumental value. To be sure, revulsion is notoriously unreliable as a moral guide. More often than not it arises from prejudice and superstition, rather than a sensitive moral compass. Again, my question is not whether a line of metaphysical metaethical thinking is sound, but whether it can have a real role to play in our practical

Worldviews, Vol 8, No. 2-3 (June 2004): pg. 185-197. DOI. This article is @ Brill Academic Publishers and permission has been granted for this version to appear in e-Publications@Marquette. Brill Academic Publishers does not grant permission for this article to be further copied/distributed or hosted elsewhere without the express permission from Brill Academic Publishers. 
decisions. It seems clear to me that the sort of revulsion that many have in considering the prospect of so-called "Frankenfoods" can be the occasion for explicitly metaphysical thinking concerning the value of biological species, and how this is to be understood from an ecological perspective. One is led to reflect on whether we ascribe goodness to individuals that belong to certain kinds, or to the kind itself, or the ecosystem in which it plays a role, given some ontological standing. This kind of metaphysical thinking can be decisive in one's rejection of less dramatic forms of genetic alteration in agriculture. Were one to start by considering the issue of the ethical permissibility of altering a crop to make it less susceptible to drought, one would probably find it permissible. It is the imaginative thought experiment of the unusual case that focuses attention on the metaphysical thesis concerning the value of biological kinds, and such attention leads to a moral precept that is adopted and employed in all cases that one takes to be applicable. ${ }^{12}$

Now in this case an anti-metaphysical "out" is available: one could always say in response to the revulsion occasioned by certain products of genetic engineering or other reproductive technologies that all that our feelings show is that we do not like these things. ${ }^{13}$ Accordingly, one could argue that the disvalue or evil that we think is present is merely a matter of our own distress. Routley sets up his thought experiment to try to render such a suggestion inapplicable. Again, whether he does so successfully is controversial, and it is not my present task to defend him here. I merely want to maintain the practical value of his work. The metaphysical implications of Routley's ethical thought experiment are clearer than those that rest on imaginative explorations of monstrosities brought about by genetic engineering. Even those who share a moral revulsion at the prospects of various forms of genetically engineered organisms are in principle able to account for them as their feelings, worthy of moral consideration only as feelings among other feelings, and hence such as can be counterbalanced by the preferences of others. But if an argument effectively concludes that living things and the natural systems of which they form a part have intrinsic value that is not ontologically dependent on the valuer, one who follows that argument is less likely to take this value to be outweighed by the preferences of others. 
NOT THE PUBLISHED VERSION; this is the author's final, peer-reviewed manuscript. The published version may be accessed by following the link in the citation at the bottom of the page.

\section{Conclusion}

I conclude that although the sort of metaphysical accounts that underlie ethical theorizing are rarely decisive in decision-making and action, there are two kinds of circumstances in which such accounts can play a crucial role in practical decisions. First are those decisions that have unusual features that do not summon habitual ethical reactions and hence invite the application of theoretical ethical precepts that the study of metaethics and ethical theory isolate and clarify. Second, there are times in which the good of others (including organisms and systems in the natural world) is not to be analyzed as one's own good. In such a case, this good may well be given greater weight in one's ethical deliberations. This is why, contra Jamieson, students who study the purported ontological foundations of environmental ethics may well come to live in a more environmentally responsible manner. Metaphysics is not a perquisite for the recognition of ethical obligations to the natural world for its own sake. But it can help.

\section{About the Author}

Owen Goldin, Department of Philosophy, Marquette University, Milwaukee, WI 53201-1881, USA; owen.goldin@marquette.edu

\section{Notes}

1. Acknowledgments: I am grateful for the incisive comments of Dale Jamieson and an anonymous referee, and to Arun Iyer for editorial help.

2. See the Environmental Ethics Syllabus Project at http://appliedphilosophy.mtsu.edu/ISEE/

3. My focus here is whether individual reflection, of the sort encouraged by classes in philosophical ethics, has an effect on individual conduct. This question is different from (though related to) the question of the extent to which a society's general philosophical or cultural outlook determines or influences the actions of members of that society. Yi-Fu Tuan has expressed scepticism on the latter issue, see Tuan 1971.

4. I focus on Jamieson 2002: 225-43.

5. For the debates on this issue, see for example Rolston 1989, Callicott 1985 and the papers collected in The Monist 1992, Vol. 75, No. 2: The Intrinsic Value of Nature.

6. Ibid.: 232.

7. Ibid.: 243.

Worldviews, Vol 8, No. 2-3 (June 2004): pg. 185-197. DOI. This article is (C) Brill Academic Publishers and permission has been granted for this version to appear in e-Publications@Marquette. Brill Academic Publishers does not grant permission for this article to be further copied/distributed or hosted elsewhere without the express permission from Brill Academic Publishers. 
NOT THE PUBLISHED VERSION; this is the author's final, peer-reviewed manuscript. The published version may be accessed by following the link in the citation at the bottom of the page.

8. At Laws 721e-723d, the Athenian Stranger argues that laws ought to be prefaced by preludes which give the reasoning behind the law, so as to better persuade the citizens that they are to be obeyed. The preludes are to be written even though they may delve into abstruse metaphysics (as is the case for the long theological prelude of Laws 10) and, as the Stranger recognizes, most of the citizenry will be unable to fully understand the reasoning they present (722b). On this, see Bobonich 1999.

9. Jamieson 2002: 235-6.

10. Ibid.: 232

11. Routley and Routley 1980.

12. Cf. the "heuristics of fear" discussed in Jonas 1984.

13. Such an identification of nonhuman bearers of value, which falls short of moral realism, may well have some impact on moral judgment but, I am arguing, when it is given some ontological grounding it is afforded significant protection against being outweighed by the moral consideration of human desires.

\section{References}

Aristotle Nicomachean Ethics. Trans. Crisp, Roger. Cambridge: Cambridge University Press. 2000.

Bobonich, Christopher. 1999. "Persuasion, Compulsion and Freedom in Plato's Laws," in G. Fine (ed.) Plato 2: Ethics, Politics, Religion and the Soul (Oxford Readings in Philosophy). Oxford: Oxford University Press, pp. 373-403.

Callicott, J. Baird. 1985. "Intrinsic Value, Quantum Theory, and Environmental Ethics," Environmental Ethics 7: 257-275.

Jamieson, Dale. 2002. Morality's Progress: Essays on Humans, Other Animals, and the Rest of Nature. Oxford: Clarendon Press.

Jonas, Hans. 1984. The Imperative of Responsibility. Chicago: University of Chicago Press.

Rolston, Holmes. 1989. "Are Values in Nature Subjective or Objective?" in Philosophy Gone Wild. Buffalo, NY: Prometheus Books, pp. 91-117.

Routley, R. and V. Routley. 1980. "Human Chauvinism and Environmental Ethics," in D.S. Mannison, M.A. McRobbie, and R. Routley (eds) Environmental Philosophy. Canberra: Australian National University, pp. 96-189.

Tuan, Yi-Fu. 1971. "Environmental Attitudes," Science Studies 1: 215-24.

Worldviews, Vol 8, No. 2-3 (June 2004): pg. 185-197. DOI. This article is (c) Brill Academic Publishers and permission has been granted for this version to appear in e-Publications@Marquette. Brill Academic Publishers does not grant permission for this article to be further copied/distributed or hosted elsewhere without the express permission from Brill Academic Publishers. 